\title{
The Science Process Skills of Prospective Biology Teachers in Plant Cell Material Based on Gender
}

\author{
https://doi.org/10.3991/ijet.v14i19.11208 \\ Muhammad Asy'ari ${ }^{(凶)}$, Herdiyana Fitriani \\ Institut Keguruan dan Ilmu Pendidikan (IKIP), Mataram, Indonesia \\ muhammadasyari@ikipmataram.ac.id \\ Siti Zubaidah, Susriyati Mahanal \\ Universitas Negeri Malang, Indonesia
}

\begin{abstract}
This study aims to describe prospective biology teachers' science process skills in plant cell material. Components of basic process skills such as (1) observing, (2) connecting, and (3) inference, and integrated process skills such as (4) analysis, (5) hypothesis, and (6) defining variables operationally, become the science process skills components examined in this study. This research is a descriptive-quantitative study with survey method to identify science process skills of 100 prospective biology teacher (50 male and 50 female). Fifteen item tests on plant cell material were used to collect data on science process skills of the prospective teacher who was first empirically validated before use. The results showed that the science process skills of biology teacher in IKIP Mataram were significantly different on the components of $(1)$ observed $(p<0.05),(2)$ inference $(p<0.05)$, and ( 3$)$ analysis $(\mathrm{p}<0.05)$, whereas the science process skills of prospective biology teacher are generally in the moderate category (60.38).
\end{abstract}

Keywords - Science process skills, prospective biology teacher, gender

\section{Introduction}

Science learning in Indonesia which has a tendency to focus on remembering scientific concepts [1] causes students' science process skills (SPS) to be generally categorized as medium [2]. SPS which are a prerequisite for learning thinking skills [3] that are directly related to psychomotor and cognitive aspects [4] are important to learn $[2,5]$ in building knowledge and solving problems $[6,7,8]$. Learning demands that emphasize the integration of scientific processes such as observing, asking, experimenting, reasoning, communicating [9] further emphasize the importance of SPS to be taught. SPS as [10] believe has become an important tool in learning and understanding science, as well as important in improving the learning achievement of science education.

SPS are activities that scientists use in assessing information about nature $[11,12]$. SPS are defined as skills that help in learning, provide variations in methods and ways 
to conduct experiments make students active, increase student responsibility, help students understand practically, and increase their sense of responsibility for selflearning [10]. SPS are classified into two, namely basic SPS and integrated SPS [11, 11]. The basic SPS include:

- Observing

- Classifying

- Inference

- Measuring

- Communicating

- Predicting

While integrated SPS include

- Variable identification

- Formulating hypothesis

- Tabulation and describing data in the graph

- Defining variables

- Investigative design

- Conducting experiments $[13,14]$.

Science learning and the development of SPS are integrated in learning activities [15]. Mastery of SPS is believed to have a strong relationship with formal thinking skills [16]. Three conditions that must be met on learning so students can experience the learning process of SPS revealed by [17] are:

- Teachers' understanding of SPS and its' importance

- Students must be given the opportunity to practice the SPS they have

- Evaluation activities regarding the development of SPS possessed by students

The conditions described are linear with the description of the latest learning demands presented by [10] that students are expected to become individuals who have SPS and critical thinking skills and the education curriculum should be refer to these aspects.

Teachers often give assignments that are available in textbooks, worksheets, and summarize learning material so that the targeted teaching material can be resolved [5] that causes students only use basic concepts that have been learned before [18]. At the college level, [19] found that students could not comprehensively recognize the items of SPS that were tested. The implementation of meaningful-oriented learning is important $[20,12]$ to overcome these problems. The identification of the prospective teachers' SPS is also important to do to provide an overview of the prospective teachers' SPS so that recommendations for improving the implementation of learning in the future can be done well.

Gender is considered to affect the differences in student learning outcomes. Gender is a term used to distinguish male and female [21]. The results of the [22] study show that male are better than female in making scientific observations. On the other hand [23] stated that male are more confident and open-minded than female, but female 
have more curiosity and maturity better than male. Result of [24] study found that gender influences students' critical thinking skills and critical thinking dispositions. Furthermore, [25] states that male and female do not have differences in understanding concepts, but male are superior in problem-solving than female.

This study aims to describe the prospective teachers' SPS based on gender in plant cell material. Components of basic process skills such as:

- Observing

- Connecting

- Inference, and integrated process skills such as

- Analysis

- Hypothesis

- Defining variables operationally become SPS components examined in this study.

\section{Methodology}

This research is a quantitative-descriptive study with survey method to identify SPS of 100 prospective biology teacher. Fifteen items of the essay test on plant cell material were used to collect data on prospective teachers' SPS included components of basic SPS such as

- Observing

- Connecting

- Inference, and integrated SPS such as

- Analysis

- Hypothesis

- Defining variables operationally.

Test instruments were empirically validated in 25 biology students who had taken anatomy and plant development courses to determine the validity and reliability of test instruments. The instrument test results were then analyzed to determine the validity and interpretation of the instrument by comparing the value of the Pearson Correlation with the value of rtable $\mathrm{N}=25$ which is 0.396 at the 0.05 significance level. The results of testing the validity and reliability of test instruments are presented in Table 1 and Table 2 below.

Table 1. Instrument validity test results

\begin{tabular}{|c|c|c|l|}
\hline Items & Pearson Correlation & Sig. (2-tailed) & \multicolumn{1}{|c|}{ Remarks } \\
\hline Number 1 & 0.06 & 0.76 & Valid \\
\hline Number 2 & 0.78 & 0.01 & Valid \\
\hline Number 3 & 0.39 & 0.04 & Valid \\
\hline Number 4 & 0.43 & 0.02 & Valid \\
\hline Number 5 & 0.78 & 0.01 & Valid \\
\hline Number 6 & 0.46 & 0.01 & Valid \\
\hline Number 7 & 0.78 & 0.01 & Valid \\
\hline
\end{tabular}




\begin{tabular}{|c|c|c|l|}
\hline Items & Pearson Correlation & Sig. (2-tailed) & \multicolumn{1}{|c|}{ Remarks } \\
\hline Number 8 & 0.21 & 0.29 & Invalid \\
\hline Number 9 & 0.47 & 0.01 & Valid \\
\hline Number 10 & 0.50 & 0.01 & Valid \\
\hline Number 11 & 0.47 & 0.01 & Valid \\
\hline Number 12 & 0.61 & 0.01 & Valid \\
\hline Number 13 & 0.28 & 0.15 & Invalid \\
\hline Number 14 & 0.15 & 0.44 & Invalid \\
\hline Number 15 & 0.33 & 0.09 & Invalid \\
\hline
\end{tabular}

Table 2. Instrument reliability

\begin{tabular}{|c|c|}
\hline Cronbach's Alpha & N of Items \\
\hline 0.70 & 15 \\
\hline
\end{tabular}

Based on the test results it is known that the instrument was declared reliable to use to collect data of prospective biology teachers' SPS in plant cell material in plant cell material. Respondents' answers were then analyzed and then categorized into three categories, namely high, moderate, and low as presented in Table 3 below.

Table 3. Criteria for SPS [2]

\begin{tabular}{|c|l|c|}
\hline No & \multicolumn{1}{|c|}{ Category } & Score \\
\hline 1 & High & $66.67 \leq \mathrm{X}$ \\
\hline 2 & Moderate & $33.33 \leq \mathrm{X}<66.67$ \\
\hline 3 & Low & $\mathrm{X}<33.33$ \\
\hline
\end{tabular}

The sample in this study were 100 (50 male and 50 female) prospective biology education teacher. The variables in this study were analyzed using SPSS for windows software. The results of the analysis include the results of identifying differences in each component of variables based on gender.

\section{Results and Discussion}

Data on prospective biology teachers' SPS were analyzed using one sample Kolmogorov-Smirnov to determine data distribution and Levene Statistic test to find out variants of data on prospective teacher SPS. The distribution test results (normality) and variance (homogeneity) of data on prospective biology teacher SPS are presented in Table 4 below.

Table 4 shows that SPS of prospective biology teacher are normally distributed and homogeneous variants in the components

- Observing

- Inference

- Analysis, and 
- Hypothesis so that the t-test is implemented to determine the differences on these components based on gender of prospective biology teachers.

\section{Components of SPS}

- Connecting are declared to be normally distributed but not homogeneous variants, while component

- Defining variables operationally as not normally distributed so that the MannWhitney $U$ test was implemented to find out the differences between the two components.

The test results of differences in SPS of biology teacher candidates are presented in Table 5 .

Table 4. Normality and homogeneity of SPS prospective biology teachers.

\begin{tabular}{|c|c|c|c|c|c|c|c|c|}
\hline \multirow[b]{2}{*}{ Level } & \multirow[b]{2}{*}{ SPS } & \multirow[b]{2}{*}{ Gender } & \multirow[b]{2}{*}{$\mathbf{N}$} & \multirow[b]{2}{*}{ Mean } & \multicolumn{2}{|c|}{ Normality test } & \multicolumn{2}{|c|}{ Homogeneity test } \\
\hline & & & & & $p$ & Normality & $\begin{array}{l}\text { Levene } \\
\text { Statistic }\end{array}$ & $\begin{array}{c}\text { Homogene } \\
\text { ity }\end{array}$ \\
\hline \multirow{6}{*}{ Basic } & \multirow{2}{*}{ Observing } & Male & 50 & 69.16 & \multirow{2}{*}{0.59} & \multirow{2}{*}{ yes } & \multirow{2}{*}{0.28} & \multirow{2}{*}{ yes } \\
\hline & & Female & 50 & 73.66 & & & & \\
\hline & \multirow{2}{*}{ Connecting } & Male & 50 & 67.66 & \multirow{2}{*}{0.26} & \multirow{2}{*}{ yes } & \multirow{2}{*}{0.01} & \multirow{2}{*}{ no } \\
\hline & & Female & 50 & 63.66 & & & & \\
\hline & \multirow{2}{*}{ Inference } & Male & 50 & 59.00 & \multirow{2}{*}{0.35} & \multirow{2}{*}{ yes } & \multirow{2}{*}{0.54} & \multirow{2}{*}{ yes } \\
\hline & & Female & 50 & 53.50 & & & & \\
\hline \multirow{6}{*}{ Integrated } & \multirow{2}{*}{ Analysis } & Male & 50 & 64.83 & \multirow{2}{*}{0.57} & \multirow{2}{*}{ yes } & \multirow{2}{*}{0.61} & \multirow{2}{*}{ yes } \\
\hline & & Female & 50 & 58.66 & & & & \\
\hline & \multirow{2}{*}{ Hypothesis } & Male & 50 & 56.25 & \multirow{2}{*}{0.08} & \multirow{2}{*}{ yes } & \multirow{2}{*}{0.71} & \multirow{2}{*}{ yes } \\
\hline & & Female & 50 & 57.25 & & & & \\
\hline & \multirow{2}{*}{$\begin{array}{l}\text { Defining variables } \\
\text { operationally }\end{array}$} & Male & 50 & 54.47 & \multirow{2}{*}{0.01} & \multirow{2}{*}{ no } & \multirow{2}{*}{\multicolumn{2}{|c|}{ Mann-Whitney U Test }} \\
\hline & & Female & 50 & 46.53 & & & & \\
\hline
\end{tabular}

Table 5. Differences in SPS of prospective teacher based on gender

\begin{tabular}{|c|c|c|c|c|c|c|c|}
\hline \multicolumn{8}{|c|}{ Independent Samples t-Test } \\
\hline SPS & Gender & $N$ & Mean & $S D$ & $d f$ & $t$ & $p$ \\
\hline \multirow{2}{*}{ Observing } & Male & 50 & 69.16 & 9.99 & \multirow{2}{*}{98} & \multirow{2}{*}{2.15} & \multirow{2}{*}{0.03} \\
\hline & Female & 50 & 73.66 & 10.82 & & & \\
\hline \multirow{2}{*}{ Inference } & Male & 50 & 59.00 & 12.38 & \multirow{2}{*}{98} & \multirow{2}{*}{2.03} & \multirow{2}{*}{0.04} \\
\hline & Female & 50 & 53.50 & 14.51 & & & \\
\hline \multirow{2}{*}{ Analysis } & Male & 50 & 64.83 & 10.55 & \multirow{2}{*}{98} & \multirow{2}{*}{2.89} & \multirow{2}{*}{0.01} \\
\hline & Female & 50 & 58.66 & 10.77 & & & \\
\hline \multirow{2}{*}{ Hypothesis } & Male & 50 & 56.25 & 11.36 & \multirow{2}{*}{98} & \multirow{2}{*}{0.41} & \multirow{2}{*}{0.67} \\
\hline & Female & 50 & 57.25 & 12.64 & & & \\
\hline \multicolumn{8}{|c|}{ Mann-Whitney Test } \\
\hline SPS & Gender & $N$ & Mean & $S D$ & $\Sigma N$ & & $p$ \\
\hline \multirow{2}{*}{ Connecting } & Male & 50 & 67.66 & \multirow{2}{*}{11.87} & \multirow{2}{*}{100} & \multirow{2}{*}{\multicolumn{2}{|c|}{0.08}} \\
\hline & Female & 50 & 63.66 & & & & \\
\hline \multirow{2}{*}{ Defining operationally } & Male & 50 & 54.47 & \multirow{2}{*}{9.93} & \multirow{2}{*}{100} & \multirow{2}{*}{\multicolumn{2}{|c|}{0.14}} \\
\hline & Female & 50 & 46.53 & & & & \\
\hline
\end{tabular}


Based on Table 5, it can be seen that the SPS of prospective biology teacher differ significantly in the components of basic SPS $(1)$ observing $(p<0.05)$ where the component of observing female prospective biology teacher is better (mean $=73.66$ ) than male $($ mean $=69.16$ ). Male prospective biology teacher in the basic SPS component are better in the component $(2)$ inference $($ mean $=59.00)$ than female $($ mean $=53.50)$ with a significant difference $(\mathrm{p}<0.05)$, while $(3)$ connecting skill of prospective biology teacher did not differ significantly $(p>0.05)$ in the basic SPS component.

The integrated SPS of prospective biology teacher are only significantly different $(\mathrm{p}<0.05)$ in component (4) analysis, where male have better analysis skills (64.83) than female (58.66), while (5) hypothesis $(p>0.05)$ and $(6)$ defining variables operationally $(\mathrm{p}>0.05)$ stated not significantly different between male and female. The research findings also show that in general the prospective biology teacher have SPS with a moderate category (60.38). Prospective biology teacher are only categorized as high on the observing component of basic SPS, as presented in Table 6 below.

Table 6. Prospective biology teachers' SPS.

\begin{tabular}{|c|c|c|c|c|c|}
\hline Level & SPS & Gender & $\mathbf{N}$ & Mean & Category \\
\hline \multirow{6}{*}{ Basic } & \multirow{2}{*}{ Observing } & Male & 50 & 69.16 & High \\
\hline & & Female & 50 & 73.66 & High \\
\hline & \multirow{2}{*}{ Connecting } & Male & 50 & 67.66 & High \\
\hline & & Female & 50 & 63.66 & Medium \\
\hline & \multirow{2}{*}{ Inference } & Male & 50 & 59.00 & Medium \\
\hline & & Female & 50 & 53.50 & Medium \\
\hline \multirow{6}{*}{ Integrated } & \multirow{2}{*}{ Analysis } & Male & 50 & 64.83 & Medium \\
\hline & & Female & 50 & 58.66 & Medium \\
\hline & \multirow{2}{*}{ Hypothesis } & Male & 50 & 56.25 & Medium \\
\hline & & Female & 50 & 57.25 & Medium \\
\hline & \multirow{2}{*}{\begin{tabular}{|l} 
Defining \\
variables \\
operationally
\end{tabular}} & Male & 50 & 54.47 & Medium \\
\hline & & Female & 50 & 46.53 & Medium \\
\hline \multicolumn{4}{|l|}{ Averages } & 60.38 & Medium \\
\hline
\end{tabular}

The results show that the basic SPS of IKIP Mataram prospective biology teacher were significantly different in the basic SPS components (1) observing $(p<0.05)$, (2) inference $(\mathrm{p}<0.05)$, and $(3)$ analysis $(\mathrm{p}<0.05)$, where male were more skilled in analyzing (mean $=64.83)$ than female $($ mean $=58.66)$ and more skilled (mean $=$ $59.00)$ in making inferences than female (mean $=53.50)$. Female prospective biology teacher were more skilled (mean $=73.66)$ in observing than male $($ mean $=69.16)$. In line with the results of the study, [26] found that male think more analytically and flexibly than female, while [27] states female are less skilled in abstract and logical thinking. A different opinion was conveyed by [28] which states that male and female are not different in concepts understanding, but male are better at solving problems than female. 
The results of this study show that prospective biology teacher are not significantly different in the connecting, hypothesis and defining variables operationally components. On thinking skills [29] stated that male and female were not different and did not correlate significantly. A different opinion was conveyed by [30] that gender differences can affect students' thinking skills. Furthermore, [23] stated that SPS affect students' high-level thinking skills, where student gender differences can influence thinking dispositions such as inquisitiveness, maturity, self-confidence, and open-mindedness.

The results of the study also showed that in general the SPS of prospective biology teachers were categorized as moderate (mean $=60.38$ ), but it should be noted, the hypothesis component had a low category. Learning activities of SPS hypothesize closely related to SPS interpreting observations and estimates. In addition, this type of SPS is also closely related to students' initial knowledge. Student SPS are influenced by the ability to formulate questions [31]. Students have difficulties on formulating hypotheses because they are not used to doing these activities and are not used to formulating scientific questions that can be tested in laboratory activities. Furthermore, [32] states the formulation of questions in learning is mostly submitted by teachers than students. SPS that are often associated with inquiry learning require students to construct knowledge through systematic steps which can be facilitated by a student-centered approach with an emphasis on knowledge construction and processes [31].

Defining variables operationally is also an indicator of identified SPS having a low score. Defining variables operationally is a statement that describes how certain variables must be measured, or how an object or condition must be recognized. Defining variables operationally skills determine the skills of students in designing problem solving in inquiry activities [3] The results of the study largely show the advantages of implementing inquiry learning [33], but barriers to implementing independent learning such as teacher preparation [34], difficulty controlling the class [35] and student despair [36] must also be considered to achieve maximum results. The low level of skill in defining variables operationally for prospective teacher students seems reasonable, given these obstacles. Furthermore, [32] stated that teachers tend don't want students to ask questions or ideas for fear of losing control in class and students tend to need a lot of time to find ideas.

\section{Conclusion}

Based on the results of the study it can be concluded that prospective biology teacher at IKIP Mataram differ significantly in indicators:

- Observe

- Inference

- Analysis

- Male prospective biology teacher are more skilled in analyzing and making inferences than female, while female are more skilled only in indicators of observing than male. 
The prospective biology teachers' SPS are generally categorized as moderate with indicators

- Hypotheses

- Defining variables operationally, being the lowest score SPS indicator. Students should be given the opportunity to implement their SPS through inquiry activities in the classroom and laboratory. Students were satisfied and felt an increase in learning outcomes after inquiry learning [37] and considered effective to increase students' declarative, procedural and conditional knowledge [38].

\section{Acknowledgement}

We would like to thank to Ministry of Research, Technology and Higher Education of the Republic of Indonesia who have provided funding support in the completion of this study.

\section{References}

[1] Prayitno, B. A., Corebima, D., Susilo, H., Zubaidah, S., \& Ramli, M. (2017). Closing the science process skills gap between students with high- and low-level academic achievement. Journal of Baltic Science Education, 16(2), 266-277

[2] Andini, T. E., Hidayat, S., Fadillah, E. N., Perrmana, T. I. (2018). Scientific process skills: Preliminary study towards senior high school student in Palembang. JPBI (Jurnal Pendidikan Biologi Indonesia), 4(3), 243-250. https://doi.org/10.22219/jpbi.v4i3.6784

[3] Nur, M. (2011). Modul Keterampilan-keterampilan Proses Sains. Surabaya: Pusat Sains dan Matematika Sekolah Universitas Negeri Surabaya.

[4] Akani, O. (2015). Levels of possession of science process skills by final year students of colleges of education in South Eastern States of Nigeria. Journal of Education and Practice, 6(27), 94-102.

[5] Wahyuni, S., Indrawati, I., Sudarti, S., \& Suana, W. (2017). Developing Science Process Skills and Problem-Solving Abilities Based on Outdoor Learning in Junior High School. Jurnal Pendidikan IPA Indonesia, 6(1), 165-169. https://doi.org/10.15294/jpii.v6i1.6849

[6] Özgelen, S. (2014). Students' science process skills within a cognitive domain framework. EURASIA Journal of Mathematics, Science and Technology Education, 10(4), 283-292. https://doi.org/10.12973/eurasia.2012.846a

[7] Turiman, P., Omar, J., Daud, A. M., \& Osman, K. (2012). Fostering the 21st century skills through scientific literacy and science process skills. Procedia - Social and Behavioral Sciences, 59, 110-116. https://doi.org/10.1016/j.sbspro.2012.09.253

[8] Lee, M. (2006). What does constructivism suggest for science education. Northridge: California State University.

[9] Kemendikbud. (2012). Dokumen Kurikulum 2013. Jakarta: Kementrian Pendidikan dan Kebudayaan.

[10] Aktamis, H. \& Yenice, N. (2010). Determine of The Science Process Skills and Critical Thinking Skill Levels. Procedia Social and Behavioral Science 2, 3282-3288. https://doi.org/10.1016/j.sbspro.2010.03.502 
[11] Aydogdu, B. (2015). The investigation of science process skills of science teachers in terms of some variables. Educational Research and Reviews, 10(5), 582-594. https://doi.org/10.5897/ERR2015.2097

[12] Molefe, L., Stears, M., \& Hobden, S. (2016). Exploring student teachers' views of science process skills in their initial teacher education programmes. South African Journal of Education, 36(3), 1-12. https://doi.org/10.15700/saje.v36n3a1279

[13] Ongowo, R. O., \& Indoshi, F. C. (2013). Science process skills in the Kenya certificate of secondary education biology practical examinations. Creative Education, 4(11), 713-717. https://doi.org/10.4236/ce.2013.411101

[14] Rezba, R. J., Sprague, C., \& Fiel, R. (2003). Learning and assessing science process skills. Kendall/Hunt Pub. Co.

[15] Subali, B., Paidi, \& Mariyam, S. (2016). The divergent thinking of basic skills of sciences process skills of life aspects on natural sciences subject in Indonesian elementary school students. In AsiaPacific Forum on Science Learning and Teaching (Vol. 17, pp. 1-23).

[16] Foulds, W., \& Rowe, J. (1996). The enhancement of science process skills in primary teacher education students. Australian Journal of Teacher Education, 21(1), 16-23. https://doi.org/10.14221/ajte.1996v21n1.2

[17] Talisayon, V. M. (2007). Development of Scientific Skills and Values in Physics Education. Retrived from http://web.phys.ksu.edu/icpe/Publications/teach2/Talisayon.pdf

[18] McBride, D. L., Zollman, D., \& Rebello, N. S. (2010). Method for analyzing students' utilization of prior physics learning in new contexts. Physical Review Special TopicsPhysics Education Research, 6(2), 1-10 https://doi.org/10.1103/PhysRevSTPER.6.020101

[19] Fitriani, H. (2016). Identifikasi Keterampilan Proses Sains Mahasiswa Biologi Ditinjau Dari Penyelesaian Lembar Kegiatan (LKM) Mahasiswa Anatomi dan Perkembangan Tumbuhan. Jurnal Ilmiah Biologi "Bioscientist". 4(1), 1-8.

[20] Molefe, L., \& Stears, M. (2014). Rhetoric and reality: Science teacher educators' views and practice regarding science process skills. African Journal of Research in Mathematics, Science and Technology Education, 18(3), 219-230. https://doi.org/10.1080/10288457. 2014.942961

[21] Fin, L. S. \& Ishak, Z. (2012). A priori model of students' academic achievement: the effect of gender as moderator. Procedia-Social and Behavioral Sciences, 65, 1092-1100. https://doi.org/10.1016/j.sbspro.2013.02.122

[22] Jegede, O. J., \& Okebukola, P. A. (1991). The relationship between African traditional cosmology and students' acquisition of a science process skill. International Journal of Science Education, 13:1, 37-47. https://doi.org/10.1080/0950069910130104

[23] Fitriani, H., Asy'ari, M., Zubaidah, S., \& Mahanal, S. (2018). Critical Thinking Disposition of Prospective Science Teachers at IKIP Mataram, Indonesia. Journal of Physics: Conference Series, (Vol 1108, pp. 1-6). https://doi.org/10.1088/17426596/1108/1/012091

[24] Ernst, J., A., \& Monroe, M,. (2004). The effects of environment-based education on students' critical thinking skills and disposition toward critical thinking, Environmental Education Research, 10(4), 507-522. https://doi.org/10.1080/1350462042000291038

[25] Gok, T. (2014). Peer instruction in the physics classroom: effects on gender difference performance, conceptual learning, and problem solving, Journal of Baltic Science Education, 13(6), 776-789. https://doi.org/10.1007/s10763-014-9546-9

[26] Dagun, S. M. D. (1992) Maskuline dan Feminisme: Perbedaan Pria dan Wanita dalam Fisiologi, Psikologi, Seksual, Karier dan Masa Depan. Jakarta: PT. Rineka Cipta.

[27] Krutetskii, V. A. (1976). The Psychology of Mathematical Abilities in School children. Chicago: University of Chicago Press. 
[28] Fuad, N. M., Zubaidah, S., Mahanal, S., \& Suarsini, E. (2017). Improving junior high schools' critical thinking skills based on test three different models of learning. International Journal of Instruction, 10(1), 101-116.https://doi.org/10.12973/ iji.2017.1017a

[29] Taghva, F., Rezaei, N., Ghaderi, J., \& Taghva, R. (2014) Studying the relationship between critical thinking skills and students' educational achievement (eghlid universities as case study) International Letters of Social and Humanistic Sciences, 25, 18-25. https://doi.org/10.18052/www.scipress.com/ILSHS.25.18

[30] Yenice, N. (2011). Investigating pre-service science teachers' critical thinking dispositions and problem-solving skills in terms of different variables. Educational Research and Reviews, 6, 497-508.

[31] Bunterm, T., Lee, K., Kong, J. N. L., Srikoon, S., Vangpoomyai, P., Rattanavongsa, J., \& Rachahoon, G. (2014). Do Different Levels of Inquiry Lead to Different Learning Outcomes? A comparison between guided and structured inquiry, International Journal of Science Education, 36(12), 1937-1959. https://doi.org/10.1080/09500693.2014.886347

[32] Gai, L., Zheng, C., Lederman, N., G., Lederman, J., S., \& Jiao, H. (2019). Development of the instrument of question-answer process (IQAP) and its application in examining salient characteristics between pre- and in-service teachers in senior high school chemistry class," International Journal of Science Education, 1-18, DOI: https://doi.org/10.1080/09500693 .2019 .1597995

[33] Berg, C. A. R., Bergendahl, V. C. B., Lundberg, B., \& Tibell, L. (2003). Benefiting from an open-ended experiment? A comparison of attitudes to, and outcomes of, an expository versus an open-inquiry version of the same experiment. International Journal of Science Education, 25(3), 351-372. https://doi.org/10.1080/09500690210145738

[34] Shedletzky, E., \& Zion, M. (2005). The essence of open-inquiry teaching, Science Education International, 16(1), 23-38.

[35] Deters, K. (2004). Inquiry in the chemistry classroom. The Science Teacher, 71(10), 4245.

[36] Trautmann, N., MaKinster, J., \& Avery, L. (2004, April). What makes inquiry so hard? (and why is it worth it?). Paper presented at the 77th annual meeting of the National Association for Research in Science Teaching, Vancouver, BC, Canada.

[37] Sadeh, I., \& Zion, M. (2012). Which type of inquiry project do high school biology students prefer: Open or guided? Research in Science Education, 42, 831-848. https://doi.org/10.1007/s11165-011-9222-9

[38] Asy'ari, M., Ikhsan, M., \& Muhali. (2019). The Effectiveness of Inquiry Learning Model in Improving Prospective Teachers' Metacognition Knowledge and Metacognition Awareness. International Journal of Instruction, 12(2), 455-470. https://doi.org/10. $\underline{\text { 29333/iji.2019.12229a }}$

\section{$7 \quad$ Authors}

Muhammad Asy'ari is lecturer in Sport and Health Department and member of Central Study of Science and Mathematics Education, Institut Keguruan dan Ilmu Pendidikan (IKIP) Mataram, Indonesia. Email id: muhammadasyari@ikipmataram.ac.id

Herdiyana Fitriani is lecturer in Biology Education, Faculty of Mathematics and Science Education and member of Central Study of Science and Mathematics Education, Institut Keguruan dan Ilmu Pendidikan (IKIP) Mataram, Indonesia. 
Siti Zubaidah is Professor at Biology Department, Universitas Negeri Malang, Indonesia and member of National Reviewer of Lecturer Research Program, Ministry of Research, Technology and Higher Education, Republic of Indonesia.

Susriyati Mahanal is Associate Professor at Biology Department, Universitas Negeri Malang, Indonesia and member of National Reviewer of Lecturer Research Program, Ministry of Research, Technology and Higher Education, Republic of Indonesia.

Article submitted 2019-07-05. Resubmitted 2019-09-12. Final acceptance 2019-09-13. Final version published as submitted by the authors. 